\title{
NESTING EFECTIVENESS OF RED MASON BEE OSMIA RUFA (L.) IN REED STALK PHRAGMITES AUSTRALIS (CAV.)
}

\author{
Paweł Michołap ${ }^{1 *}$ \\ Marcin Cierpisz ${ }^{2}$ \\ Aneta Sikora ${ }^{1,3}$ \\ Marcin Sikora ${ }^{1,4}$ \\ ${ }^{1}$ Natura i Człowiek Association, Legnicka 65, 54-206 Wrocław, Poland \\ 'Wrocław University of Environmental and Life Science, Department of Plant \\ Protection, pl. Grunwaldzki 24A, 50-363 Wrocław, Poland \\ 3Karkonoski National Park, Chałubińskiego 23, 58-570 Jelenia Góra, Poland \\ ${ }^{4}$ Centrum Nauki Keplera - Centrum Przyrodnicze, Gen. J. Dąbrowskiego 14, 65-021 \\ Zielona Góra, Poland
}

*corresponding author: micholap.pawel@gmail.com

Received: 25 February 2020; accepted: 20 October 2020

\begin{abstract}
A b s t r a c t
The research enabled the optimal parameters of reed stalks Phragmites australis (Cav.) Trin. ex Steud, to be determined and then be used for rearing red mason bees (Osmia rufaL.). During research conducted in 2015 and 2016, 3,293 reed stalks were occupied by red mason bees, and 19,461 nest cells were counted in the stalks, of which there were 16,222 non-parasitized larvae. The mean weight of one cocoon was $0.085 \mathrm{~g}$. The mean length of the reed stalk occupied by the red mason bee was $169.45 \mathrm{~mm}$, its mean diameter was $6.11 \mathrm{~mm}$ and the mean number of cells in the reed was 5.47 . The mean length of the first cell, the vestibulum, was $38.38 \mathrm{~mm}$. The mean degree of parasitism was 0.16 . The length of the reed stalk positively correlated with the number of cells in the reed nest $(r=0.543)$, vestibulum length $(r=0.392)$ and cocoon mass $(r=0.362)$ The diameter of the reed positively correlated with the mass of the cocoon $(r=0.536)$, the number of cells in the reed $(r=0.406)$ and vestibulum length $(r=0.254)$. Correlation between degree of parasitatism and length, and diameter of the reed was insignificant. Reed stalks with a length of 150 to $200 \mathrm{~mm}$ and a diameter of $5-7 \mathrm{~mm}$ are recommended for the choice of red mason bee nesting material.
\end{abstract}

Keywords: nesting material, Osmia rufa, preferences, solitary bee management

\section{INTRODUCTION}

In recent decades, wild bee abundance and species diversity have declined all over the globe (Winfree, 2010). In temperate climates bees are essential in pollinating wild trees, shrubs and herbs and in the proper functioning of most terrestrial ecosystems (Williams, Corbet, \& Osborne, 2015). Most crops require pollination by insects (Kevan, Clark, \& Thomas, 1990), so protective measures should be taken at many levels to maintain an adequate level of food production (Losey \& Vaughan, 2006, Gruber et al., 2011). Precise recognition of bee ecology is a key to maintaining the stability and species richness of many habitats (Steffan-Dewenter \& Schiele, 2004).

Currently, solitary bees are used as pollinators for various crops. Among the species from the Megachilidae family, many have proven to be highly effective pollinators used in agriculture, including the alfalfa leafcutter bee Megachile rotundata (F.) for alfalfa pollination and the red mason bee Osmia rufa (L.) for orchard pollination (Free \& Williams, 1970; Holm, 1973). Research on the pollination effect using red mason bee 0 . rufa in Poland was conducted on rape (Teper \& Biliński 2009) and blackcurrants (Fliszkiewicz, Giejdasz, \& Wilkaniec, 2011) and strawberries cultivated in greenhouses (Wilkaniec 
\& Radajewska, 1997) and onion cultivated for seeds (Wilkaniec, Giejdasz, \& Prószyński, 2004). The red mason bee Osmia rufa (L.), a West Palaearctic species, is widespread in Europe and Central Asia (Banaszak \& Romasenko, 2001). It is a solitary bee species that actively pollinates in temperatures over $15^{\circ} \mathrm{C}$. It can hibernate for a maximum of 150 days and survive wintering temperatures down to $-31^{\circ} \mathrm{C}$ (Krunić \& Stanisavljević, 2006b), but its highest survival rate is recorded at wintering temperature of $0^{\circ} \mathrm{C}$ (Bosch \& Kemp, 2004). This bee's short flight periods in the natural environment considerably limits its usefulness for plant breeders, and in order to change this wintering period in cocoons is lengthened. By maintaining a temperature of $4^{\circ} \mathrm{C}$ up to the time of plant blooming. This treatment shortens the lifetime of the insects, which could be the result of oxidative stress (Dmochowska et al., 2012). The favourable sex ratio, the relatively easy acquisition of this species from nature and rearing simplicity makes the red mason bee an alternative to other commercially used pollinators (Holm, 1973, Gruber et al., 2011).

The wide host plant spectrum of 0 . rufareaches over 150 plant species (Ruszkowski \& Biliński, 1986) including anemophilous trees - Fagus, Juglans, Pinus, Quercus, and weeds - Plantagoand Rumex (Teper, 2007). The red mason bee builds its nests in various cavities, most often in empty plant stems, wood holes made by xylophagous beetles and empty snail shells (Raw, 1972) and willingly occupies artificial nests composed from reed stalks or other materials. Very often, the female bees lay their eggs in places where they emerged themselves (Ivanov, 2006). Important factors in the rearing of this species and understanding its biology are how individuals choose nesting sites (the stalk length and the diameter of the cavity inlet of the stalk where the nests are built) and linking nest parameters with the condition of the bees' next generation (number of nest cells in the reed, cocoon mass, rate of parasitism) (Bosch \& Vicens, 2002).

The aim of the study was to determine the optimal features of the Phragmites australis (Cav.) Trin. ex Steud stalks for occupation by
Osmia rufa L. We identified reed features that guaranteed the most efficient way of occupation by 0 . rufa bees.

\section{MATERIAL AND METHODS}

Red mason bees Osmia rufa were reared in stalks of the common reed Phragmites australis, and its cocoons used in the research came from local populations reared for three years at the Wrocław University of Life and Environmental Sciences. The stalks were cut in such a way that one side was blinded with a node diaphragm and the other side had an inlet cave. Stalks were cut from currently available reeds for $30 \mathrm{~mm}$ to $330 \mathrm{~mm}$ long nests. No stalks below $3 \mathrm{~mm}$ in diameter were used because such stalks are not occupied by the red mason bee. Next, the material was packed into bundles fifty stalks of random diameter and length. The bundles were placed in wood boxes sheltered from rain and direct sunlight. The nests were exposed to the south.

The rearing was carried out in 2015 and 2016 in three places: the Medicinal Plant Garden, Wrockaw (Poland, Lower Silesia, 51 $07^{\prime} 04^{\prime \prime} \mathrm{N}$, $\left.17^{\circ} 04^{\prime} 29^{\prime \prime} \mathrm{E}\right)$, a housing estate in the Kozanów district, Wrocław (Poland, Lower Silesia, $\left.51^{\circ} 08^{\prime} 10^{\prime \prime} \mathrm{N}, 16^{\circ} 58^{\prime} 42^{\prime \prime} \mathrm{E}\right)$ and a garden plot in Kamionki village (Poland, Lower Silesia, $\left.50^{\circ} 40^{\prime} 36^{\prime \prime} \mathrm{N}, 16^{\circ} 32^{\prime} 35^{\prime \prime} \mathrm{E}\right)$. In total, for two years of research 5,000 stems of reed were exposed (Medicinal Plant Garden 2,536; Kozanów 1,057; Kamionki 1,407).

The cocoons were winterized and placed next to the nesting material in a cardboard box. In 2015, 1,000 cocoons were placed outdoors, while in 2016 all 3,500 cocoons from the previous year were put out. In September, all occupied reeds were taken from the rearing spots and kept in a refrigerator at a stable temperature of $4^{\circ} \mathrm{C}$.

In December, each stalk was cut with a knife on two sides and split. The cocoons were removed from the stalks, and cleaned of excrement, pollen and parasite residue. For each stalk, the length, diameter, vestibulum length (the empty cell at the entrance of the tube) and the contents of every cell were measured. The length of the reed 
from the inlet to the node was measured using a ruler with an accuracy of $1 \mathrm{~mm}$. To measure the diameter of the inlet, an electronic calliper was used with an accuracy of $0.01 \mathrm{~mm}$. Each parasite-free cocoon was weighed on an electronic scale with an accuracy of $0.001 \mathrm{~g}$. Average mass of cocoons from one nest was used to estimate the correlation between variables. The rate of parasitism for each nest was defined as the number of parasitized larvae in relation to the total number of cells (1 parasitism rate $=100 \%$ parasitism). The diameter and length of the unoccupied stalks were also measured. Reeds were graded in $50 \mathrm{~mm}$ increments (7 ranges: $<50 \mathrm{~mm}$, from 50 to $100 \mathrm{~mm}$, from 100 to $150 \mathrm{~mm}$, from 150 to $200 \mathrm{~mm}$, from 200 to $250 \mathrm{~mm}$, from 250 to $300 \mathrm{~mm}$ and from 300 to $350 \mathrm{~mm}$ ) and diameter in $1 \mathrm{~mm}$ increments (7 ranges: from 3 to $4 \mathrm{~mm}$, from 4 to $5 \mathrm{~mm}$, from 5 to $6 \mathrm{~mm}$, from 6 to $7 \mathrm{~mm}$, from 7 to $8 \mathrm{~mm}$, from 8 to $9 \mathrm{~mm}$ and from 9 to $10 \mathrm{~mm}$ ). The size of each category was classified according to the percentage of stalks unoccupied compared to the occupied for showing which one range was the most occupied by red mason bee.

The parameters of cell number, vestibulum length, and parasitism rate were analyzed. Values in the text and figures are given as median (Me) with Interquartile Range (Q1 the median of the lower half of the data set; Q3 the median of the upper half of the data set) and mean \pm standard deviation unless otherwise stated. In order to show the influence dependence of the diameter and length of stalks on cells number in the reed, cocoon mass, vestibulum length and parasitism rate, the Pearson correlation coefficient was calculated. Linear relations were presented in the drawings. All statistical analyzes were performed in the Statistica v.13.3 program, and the significant level was set to $a=0.05$.

\section{RESULTS}

In total, during the two-year research, 3,293 of 5,000 stalks were occupied. There were $1,777(54 \%)$ reeds without parasites and 529 (15.03\%) nests with all parasitized cells. In the
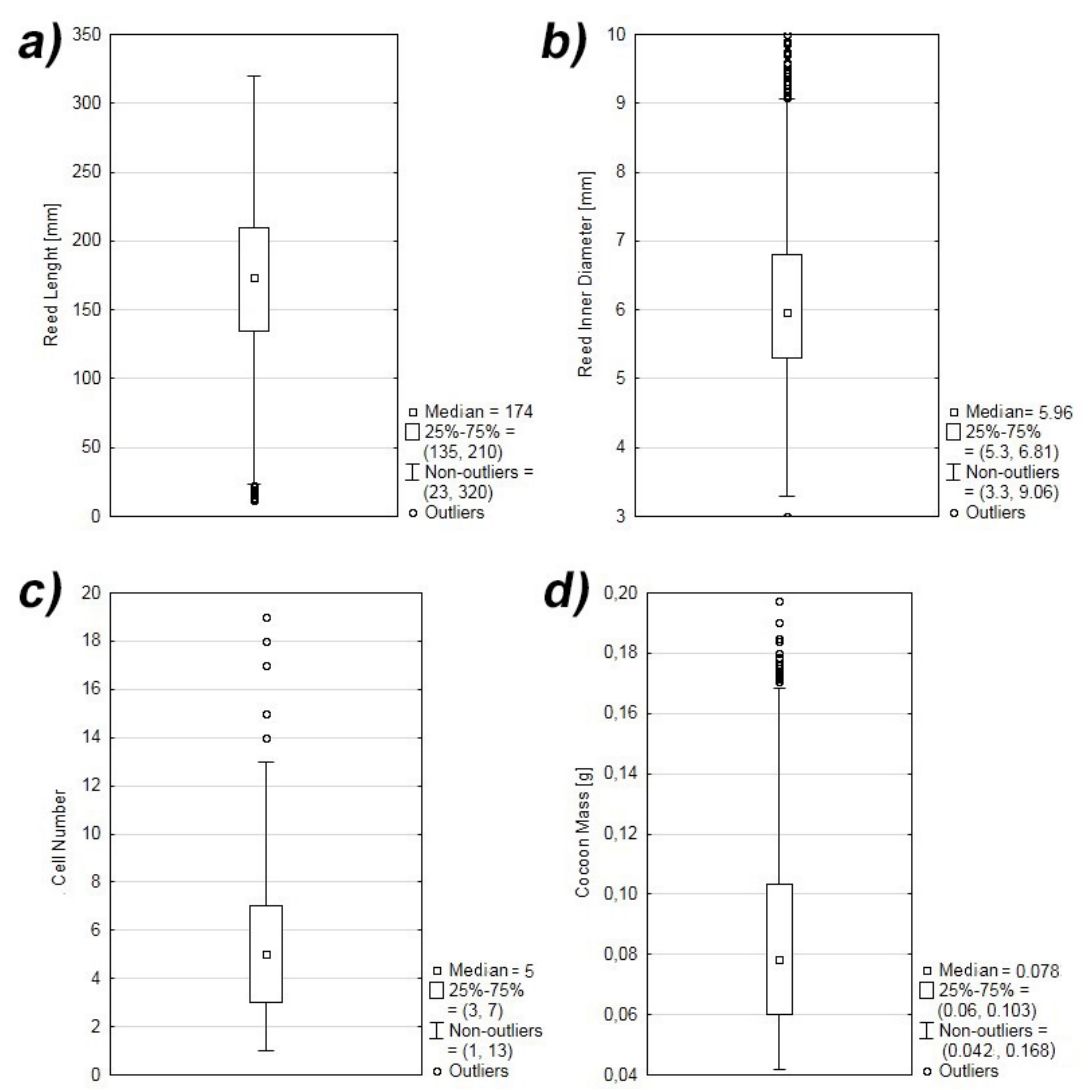

Fig. 1. Reed parameters settled by red mason bee. (a) the stalk length (b) diameter (c) cell number (d) cocoon mass. 
a)

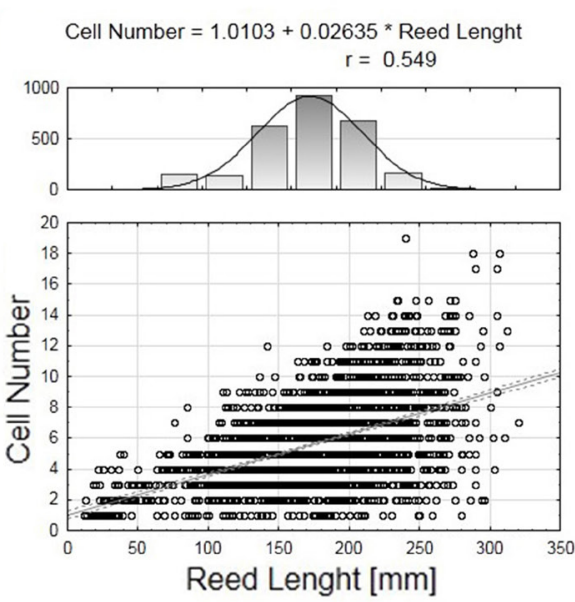

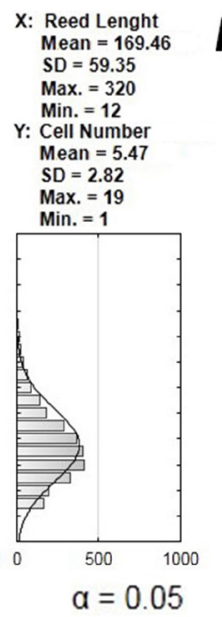

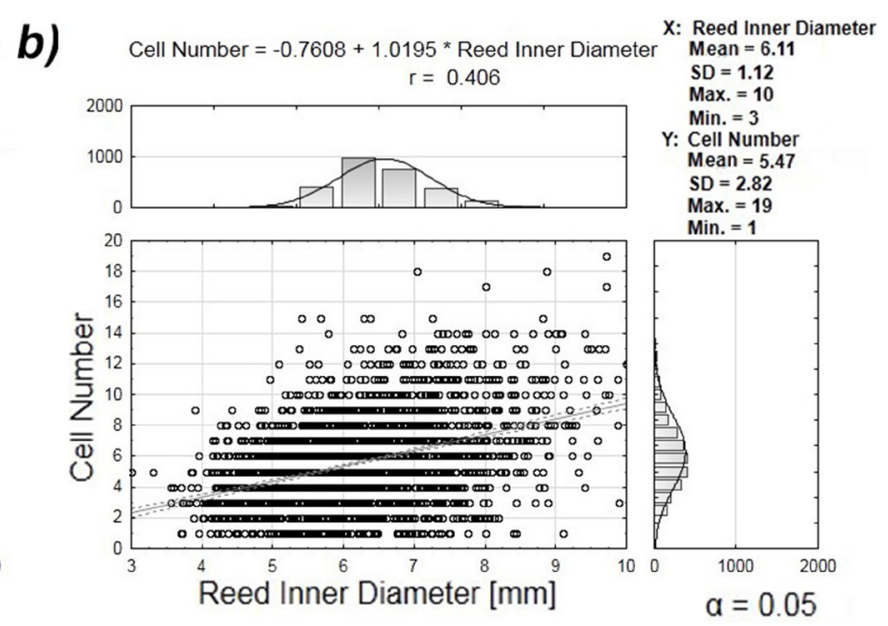

Fig. 2. Correlation between reed length (a) diameter (b) and cell number.

a)

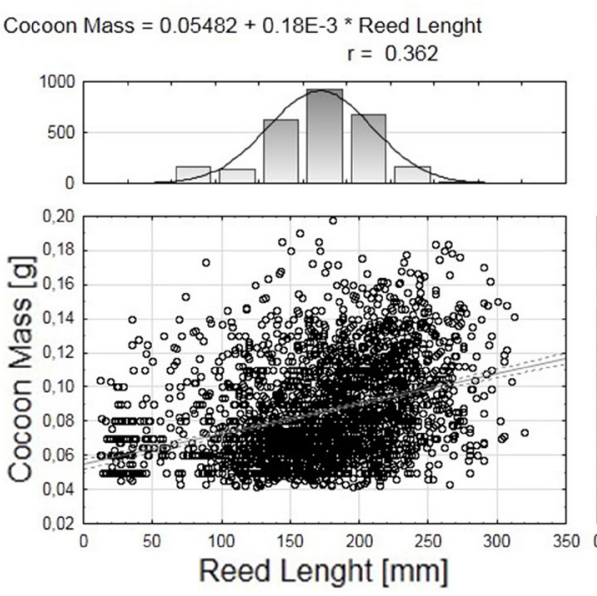

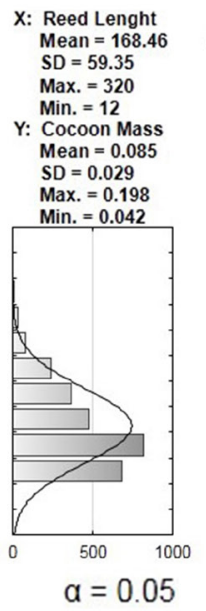

b)

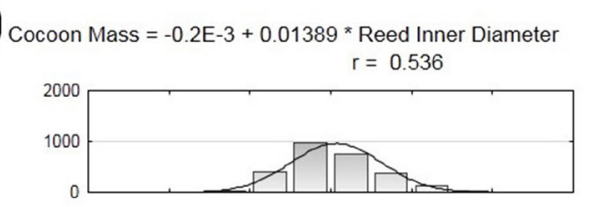

: Reed Inner Diameter Mean $=6.11$ $\mathrm{SD}=1.12$ Max. $=10$
Min. $=3$ Y: Cocoon Mass Mean $=0.085$ $\mathrm{SD}=0.029$
Max. $=0.19$ Max. $=0.198$
Min. $=0.042$
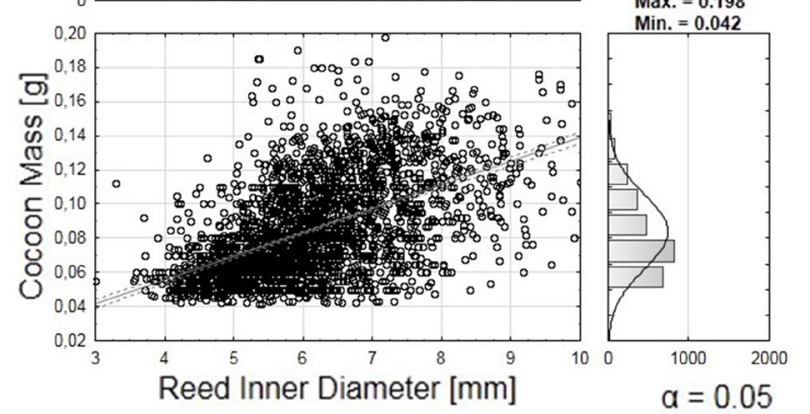

Fig. 3. Correlation between reed length (a) diameter (b) and mass of red mason bee cocoon.

a)
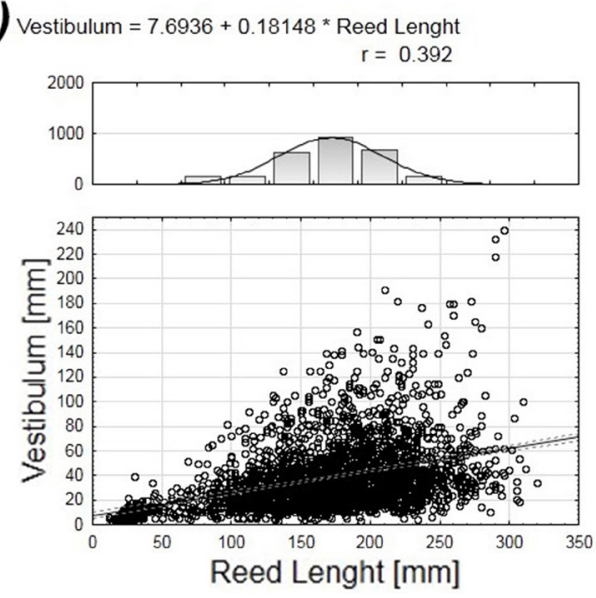

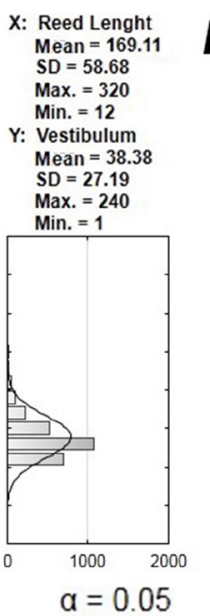

b)
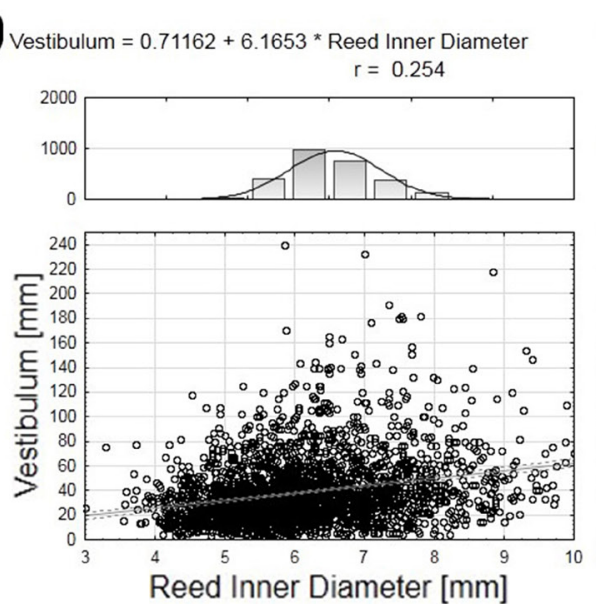

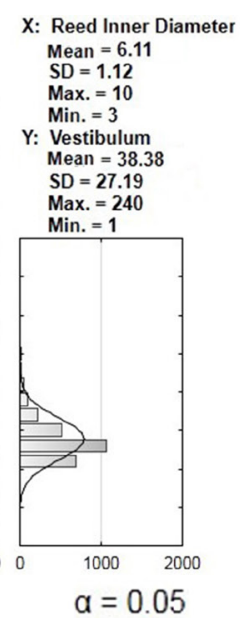

X: Reed Inner Diameter Mean $=6.11$
$\mathrm{SD}=1.12$ Max. $=10$

Vestibulum $\mathrm{SD}=27.19$ Min. $=1$

$a=0.05$

Fig. 4. Correlation between reed length (a) diameter (b) and vestibulum length. 


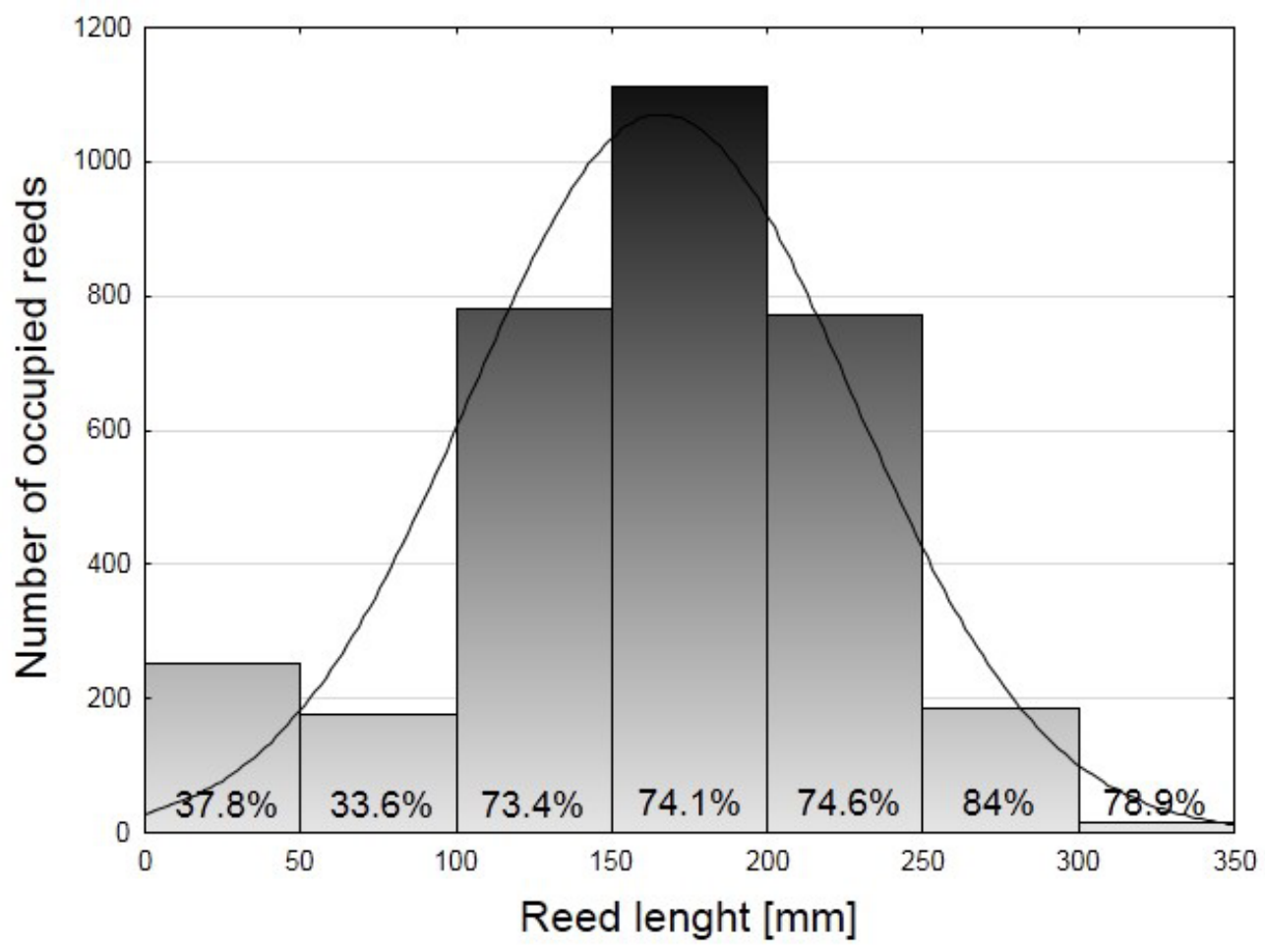

Fig. 5. The number of settled reeds within specific ranges of length (percent means the ratio of settled reeds).

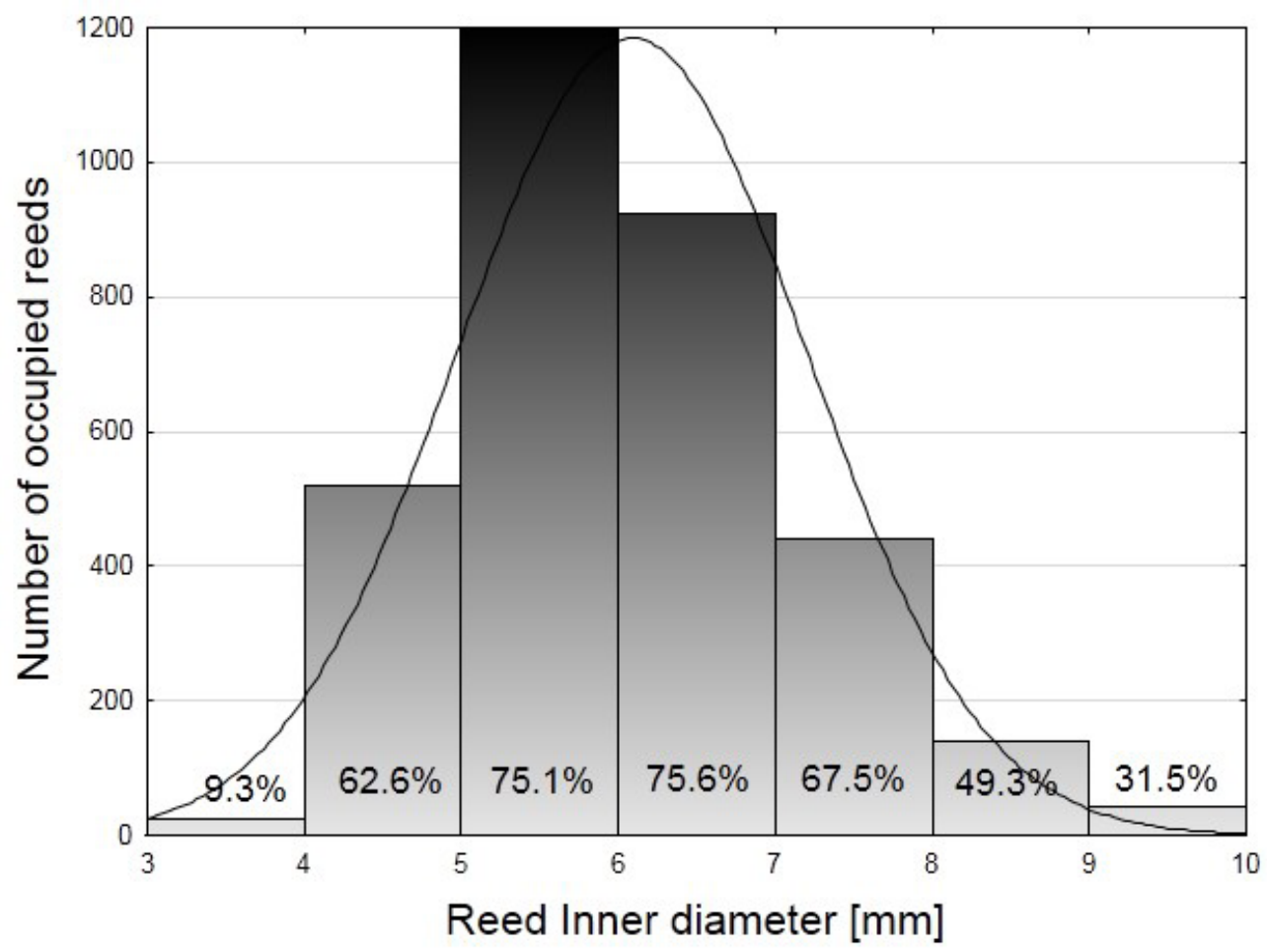

Fig. 6. The number of settled reeds in specific ranges of diameter (percent means the ratio of settled reeds). all nests, 19,641 cells were counted, in which dactylus osmiae Dufour.

there were 16,222 cocoons (3,419 larvae in cells Red mason bees settled stalks with lengths were parasitized - 17.4\%). The most common ranging from 12 to $320 \mathrm{~mm}$ (Q1=135 mm, insects parasitizing $O$. rufa during rearing were $M e=174, Q 3=210 \mathrm{~mm}$ ) (Fig. 1a). The mean length fly Cacoxenus indagator Loag, wasp Monodon- of the occupied reed was $169.45 \mathrm{~mm}$ (SD=59.35, tomerus obscurus Westwood, and mite Chaeto- $n=3,293)$. The diameter of the reed ranged from 
3 to $10 \mathrm{~mm}(\mathrm{Q} 1=5.3 \mathrm{~mm}, \mathrm{Me}=5.96 \mathrm{~mm}, \mathrm{Q} 3=6.81$ $\mathrm{mm}$ ) (Fig. 1b). The mean diameter of the occupied reed was $6.11 \mathrm{~mm}(S D=1.12, n=3,293)$. The mean number of cells in the reed was $5.47(\mathrm{SD}=2.82$, $n=19,641)$. A maximum of nineteen cells in the reed were recorded and a minimum of at least one cell ( $Q 1=3, M e=5, Q 3=7)$ (Fig. 1c). The mean mass of the cocoon was $0.085 \mathrm{~g}(\mathrm{SD}=0.029$, $\mathrm{n}=16,222)$. The cocoon mass ranged between 0.041 and $0.194 \mathrm{~g},(\mathrm{Q} 1=0.06 \mathrm{~g}, \mathrm{Me}=0.078 \mathrm{~g}$, $\mathrm{Q}=0.103 \mathrm{~g}$ ) (Fig. 1d).

The number of cells in the stalks was positively correlated with the length of the reed $(r=0.543$, $p<0.001)$ and the diameter $(r=0.406, p<0.001)$ (Fig. 2a, b). The mean mass of the cocoon was positively correlated with the length $(r=0.362$, $p<0.001)$ and the diameter of the reed $(r=0.536$, $p<0.001$ ) (Fig. 3a, b). The mean length of the first cell, the vestibulum, was $38.38 \mathrm{~mm}(\mathrm{SD}=27.19$, $n=3,293$ ) and the most common range from 70 to $90 \mathrm{~mm}$ (Fig. 4a, b). The vestibulum length was positively correlated with the length of the reed $(r=0.392, p<0.001)$ and diameter $(r=0.254$, $p<0.001)$. The mean rate of parasitism was 0.16 (SD=0.27, $n=16,222$ ). The most frequently reported rate of parasitism ranged from 0.2 to 0.3 . There was no correlation between rate of parasitism and by the diameter $(r=0.108$, $p<0.001)$, and the length $(r=-0.040, p=0.022)$. Additionally, no correlation was found between vestibulum length and parasitism rate $(r=-0.118$, $p<0.001)$.

O. rufa most commonly occupied stalks ranging from 150 to $200 \mathrm{~mm}$ in length (1113 pcs., $74.1 \%$ settled), stalks from 100 to $150 \mathrm{~mm}$ (781 pcs., $73.4 \%$ settled ) and from 200 to $250 \mathrm{~mm}$ (771 pcs., 74.6\% settled) (Fig. 5). Among the unsettled reeds, those with lengths ranging from 50 to $100 \mathrm{~mm}$ and from 0 to $50 \mathrm{~mm}$ were predominant (176 pcs., 33.6\% and 253 pcs., 37.8\% respectively, settled). The most commonly in occupied stalks ranged from 5 to $6 \mathrm{~mm}$ and from 6 to $7 \mathrm{~mm}$ in diameter (1119 pcs., $75.1 \%$ and 924 pcs., 75.6\%, respectively) (Fig. 6). Among the unsettled reeds, those with a diameter ranging from 3 to $4 \mathrm{~mm}$ as well as from 9 to $10 \mathrm{~mm}$ and from 8 to $9 \mathrm{~mm}$ (25 pcs., 9.3\%, 43 pcs., 31.5\% and 139 pcs., $49.3 \%$, respectively) prevailed.

\section{DISCUSSION}

Red mason bee is a species that relatively easily nests in all available kinds of holes in wood, crevices in buildings, reeds and even plastic pipes (Madras Majewska, Zajdel, \& Boczkowska, 2011). This species is easily used in amateur rearing for plants pollination but also in commercial orchards or plantations. The calculations demonstrated that for the effective pollination of apple, cherry and blackcurrant orchards, there is need for, 556, 3,137 and 966 females respectively are needed, or three times more cocoons, because females constitute about $33 \%$ of all emerged bees (Biliński \& Teper, 2004). In order to optimize the bee rearing, artificial nests of appropriate dimensions and material type should be selected. It is worth considering the nesting material when setting up 0 . rufa rearing. These bees reluctantly occupy artificial materials, such as plastic tubes, while most prefer natural material (Wilkaniec \& Giejdasz, 2003). In wood nests, the highest number of nested cells was recorded (Wilkaniec \& Giejdasz, 2003). However, in this type of artificial nest, the harmful mite Chaetodactylus osmiae rapidly spreads due to its rapid movement between cells and thus reproduction in new built cells. Therefore, reed stalks seem to be a good nesting material due to its cheap availability, as well as the very low mobility of Ch. osmiae mite, because each cell with larva and pollen is strictly separated from others (Krunić et al., 2005; Asselt, 2009). On the other hand, reeds can be a problem for large breeders due to the labour-intensive extraction and cleaning of the cocoons (unpubl. data). At the same time, reed stems are also a suitable nesting space for other solitary species of bees and wasps as well as other insects (Budrienè, Budrys, \& Nevronytė, 2004; Krunić et al., 2005). The diameter of the occupied stalks ranged from 3 to $10 \mathrm{~mm}$ averaged $6.11 \mathrm{~mm}$, but most often the bees settled reeds within the $5-7 \mathrm{~mm}$ range. Other studies also show a similar range of reeds populated by 0 . rufa (Budrienè, Budrys, \& Nevronytė, 2004). In an experiment with plastic straws 5 and $7 \mathrm{~mm}$ in diameter, bees were more likely to occupies those with larger diameters 
(Free \& Williams, 1970). Studies showed that more red mason bees occupied greenhouse reeds $6 \mathrm{~mm}$ in diameter than those $8 \mathrm{~mm}$ in diameter. However, those with a larger diameter had a greater ratio of emerged females to males (Holm, 1973). The sex ratio parameter, which is advantageous to females, is achieved at a reed length of at least $150 \mathrm{~mm}$ (Gruber, 2011). In our experiment the mean length of settle reeds exceeded this level and was $169.45 \mathrm{~mm}$. Seidelmann, Bienasch, \& Pröhl (2016) reported that the optimal length of nest tubes for the propagation of 0 . rufa has to be oriented on the sex ratio shift towards males in tubes shorter than $130 \mathrm{~m}$, and on practical demands as handling and procurement of nest tubes. Tubes from 8 to $10 \mathrm{~mm}$ in diameter and from 150 to $200 \mathrm{~mm}$ long were found to be optimal. Shorter stalks used for nesting were more vulnerable to parasitism, which is why females that lay their eggs in them carry less provisions to their cells. In our study the vestibulum length in the reeds did not significantly affect the rate of parasitism, but it probably depends on the environmental conditions in which the nests are located. These stalks, which are shielded from the sun, wind and sudden temperature fluctuations always have a shorter first nest cell (Seidelmann, 1999). In our case, the length of the stalk determined the length of the vestibulum and also the diameter, but to a lesser degree. As some studies have shown (Seidelmann, 1999), nesting bees that noticed the cleptoparasitic fly Cacoxenus indagator left the outermost part of the nest without provisions and sealed the inlet. It is also for protection against excessive nest parasitization.

Many brood cell parasites enter open cells during its provisioning, when the mother bee is absent. Therefore, females can reduce the risk of open-cell parasitism by limiting the time they are away from the nest (Seidelmann, 2006). The rate of nest parasitization is determined by the diameter of the stalks, so if the diameter of the reed is larger, more parasites can be expected. Also, the size of the red mason bee aggregation may affect the rate of nest parasitization, because at a higher density the parasites did not apear (Holm, 1973), which may be related to the scattering of parasites or the location of nests (Fliszkiewicz, Kuśnierczak, \& Szymaś, 2015). A higher rate of parasitism is recorded in hay meadows than in forests or orchards (Fliszkiewicz, Kuśnierczak, \& Szymaś, 2015).

The research also demonstrates that the red mason bee preferably occupies reeds if it has a choice of other nesting materials (Wilkaniec \& Giejdasz, 2003). However, it reluctantly uses reeds which had already been occupied (Bąk \& Wilde, 2003). Therefore, new nesting material should be provided every year, thereby limiting the number of parasitic organisms on 0 . rufa (Krunić \& Stanisavlejević, 2006a).

The experiment conducted by us allowed the determination of the optimal parameters of the reed stalks for nesting by the red mason bee Osmia rufa. The length and diameter of the reed had a positive effect on such parameters as the number of cells in the reed, the average mass of the cocoon, the length of the vestibulum and the rate of parasitism. Seidelmann, Bienasch, and Pröhl (2016) reported that the mass of the cocoon is not affected by the length, diameter of the reed, and the number of cells in the nest is affected by both the diameter and length of the stem. Szentgyörgyi and Woyciechowski (2013) stated that the diameter affects the size of the cocoon in mm. In addition, the diameter of the stalk affects the ratio of emerged females to males, and in the lower diameters there is a higher number of males (Seidelmann, Ulbrich, \& Mielenz, 2010). The mass of the cocoons for each occupied stalk was also measured; the mean mass of one cocoon was $0.085 \mathrm{~g}$. Considering the total number of cocoons $(16,222)$, the obtained mean value can be used for weight measurement of the number of cocoons for this species, which will help in the increasingly popular sale of this species. We know the red mason bee can be successfully used as a pollinator for early flowering fruit trees and shrubs in orchards and for greenhouse crops (Holm, 1973; Parker, Batra, \& Tepedino, 1987; Bosch, 1994; Kemp, 2000; Fliszkiewicz, Giejdasz, \& Wilkaniec, 2011). For optimal condition when choosing a nesting material for red mason bee 
rearing, it is recommended that stalks have a length of 150 to $200 \mathrm{~mm}$ and a diameter of 5-7 mm. Information obtained through statistical analysis of the collected results can be used as a model in the practical rearing of red mason bees.

\section{ACKNOWLEDGMENTS}

We are grateful to the two anonymous reviewers for their helpful comments.

\section{REFERENCES}

Asselt, L. (2009). Observations on the life cycle of Chaetodactylus osmiae (Dufour, 1839) (Acari: Chaetodactylidae) parasitic on the solitary bee, Osmia rufa (L.), 1758 (Insecta: Hymenoptera) in Belgium. International Journal of Acarology, 26(3), 221-228. DOl: 10.1080/01647950008684192

Banaszak, J., \& Romasenko, L. (2001). Megachilid Bees of Europe. Second Edition. Bydgoszcz University Press, Bydgoszcz.

Bąk, B., \& Wilde, J. (2003). The development rate of a red mason bee population Osmia rufa (L.) (Hymenoptera: Apidae) in artificial cane nests, Wiadomości Entomologiczne, 22(3), 161-167.

Bosch, J. (1994). The nesting behavior of the mason bee Osmia cornuta L. with special references to its pollinating potential (Hymenoptera, Megachilidae). Apidologie, 25, 84-93.

Bosch, J., \& Kemp, W. (2004). Effect of pre-wintering and wintering temperature regimes on weight loss, survival, and emergence time in the mason bee Osmia rufa (Hymenoptera: Megachilidae). Apidologie, Springer Verlag, 35(5), 469-479.

Bosch, J., \& Vicens, N. (2002). Body size as an estimator of production cost in a solitary bee. Ecological Entomology, 27, 129-137. DOl: 10.1046/j.13652311.2002.00406.x

Budrienè, A., Budrys, B., \& Nevronytè, A. (2004). Solitary Hymenoptera Aculeata Inhabiting Trap-Nests in Lithuania: Nesting Cavity Choice and Niche Overlap. Latvijas Entomologs, 41, 19-31.

Dmochowska, K., Giejdasz, K., Fliszkiewicz, M., \& Zóktowska, K. (2012). Changes in the antioxidative system of the red mason bee (Osmia rufa) (Hymenoptera: Megachilidae) induced by artificially elongated diapause. Journal of Apicultural Science, 56(1), 99-106.

Fliszkiewicz, M., Giejdasz, G., \& Wilkaniec, Z. (2011). The importance of male red mason bee (OsmiarufaL.) and male bufftailed bumblebee (Bombus terrestrisL.) pollination in blackcurrant (Ribes nigrum L.). The Journal of Horticultural Science and Biotechnology, 86(5), 457-460. DOl: 10.1080/14620316.2011.11512788

Fliszkiewicz, M., Kuśnierczak, A., \& Szymaś, B. (2015). Reproduction of the red mason solitary bee Osmia rufa (syn. Osmia bicornis) (Hymenoptera: Megachilidae) in various habitats. European Journal of Entomology, 112(1), 100-105. DOl: 10.14411/eje.2015.005

Free, J., \& Williams, I. (1970). Preliminary Investigations on the Occupation of Artificial Nests by Osmia rufa L. (Hymenoptera, Megachilidae). Journal of Applied Ecology, 73), 559-566. DOl: 10.2307/2401978

Gruber, B., Eckel, K., Everaars, J., \& Dormann, C. (2011). On managing the red mason bee (Osmia bicornis) in apple orchards. Apidologie, 42, 564. DOl: 10.1007/ s13592-011-0059-2

Holm, S. (1973). Osmia rufaL. (Hym. Megachilidae) as a Pollinator of Plants in Greenhouses. Entomologica Scandinavica, 4(3), 217-224.

Ivanov, S. (2006). The Nesting of Osmia rufa(L.) (Hymenoptera, Megachilidae) in the Crimea: Structure and Composition of Nests. Entomological Review, 86, 524-533. DOl: 10.1134/S0013873806050046

Kemp, W. P. (2000). The future of crop pollination. American Bee Journal, 140,851-853.

Kevan, P., Clark, E., \& Thomas, V. (1990). Insect pollinators and sustainable agriculture. American Journal of Alternative Agriculture 5(1), 13-22. D0l: 10.1017/ 


\section{J. APIC. SCLI. VOL. 64 ND. 2 2020}

\section{S0889189300003179}

Krunić, M., Stanisavlejević, L., Pinzauti, M., \& Felicioli, A. (2005). The accompanying fauna of Osmia rufa and effective measures of protection. Bulletin of Insectology, 58(2), 141-152.

Krunić, M., \& Stanisavlejević, L. (2006a). Augumentation of managed population of Osmia rufa and Osmia rufa (Hymenoptera: Megachilidae) in Southeastern Europe. European Journal of Entomology, 103, 695-697.

Krunić, M., \& Stanisavlejević, L. (2006b). Supercooling points and diapause termination in overwintering adults of orchard bees Osmia rufa (Hymenoptera: Megachilidae). Bulletin of Entomological Research, 96(3), 323-326.

Losey, J., \& Vaughan, M. (2006). The Economic Value of Ecological Services Provided by Insects. Bioscience, 56(4), 311-323. DOl: 10.1641/0006-3568(2006)56[311:TEVOES]2.0. $\mathrm{CO} ; 2$

Madras-Majewska, B., Zajdel, B., \& Boczkowska, A. (2011). The influence of nests usage on mason bee (Osmia rufaL.) survival. Annals of Warsaw University of Life Sciences - SGGW, Animal Science, 49, 115-119.

Parker, F. D., Batra, S. W. T., \& Tepedino, V.J. (1987). New pollinators for our crops. Agricultural Zoology, 2,279-304.

Raw, A. (1972). The biology of the solitary bee Osmia rufa (L.) (Megachilidae). Transactions of the Entomological Society of London, 124(3), 213-229.

Ruszkowski, A., \& Biliński, M. (1986). Rośliny pokarmowe oraz znaczenie gospodarcze murarek. Pszczelnicze Zeszyty Naukowe, 30,63-87.

Seidelmann, K. (1999). The function of the vestibulum in nest of a solitary steam-nesting bee, Osmia rufa(L.). Apidologie, 30, 19-29.

Seidelmann, K. (2006). Open-cell parasitism shapes maternal investment patterns in the Red Mason bee
Osmia rufa. Behavioral Biology, 17,839-848.

Seidelmann, K., Ulbrich, K., \& Mielenz, N. (2010). Conditional sex allocation in the Red Mason bee, Osmia rufa. Behavioral Ecology and Sociobiology, 64, 337347.

Seidelmann, K., Bienasch, A., \& Pröhl, F. (2016). The impact of nest tube dimensions on reproduction parameters in a cavity nesting solitary bee, Osmia bicornis (Hymenoptera: Megachilidae). Apidologie, 47, 114-122. DOI: 10.1007/s13592-015-0380-2

Steffan-Dewenter, I., \& Schiele, S. (2004). Nest-site fidelity, body weight and population size of the red mason bee, Osmia rufa (Hymenoptera: Megachilidae), evaluated by Mark Recapture experiments. Entomologia Generalis, 272), 123-131.

Szentgyörgyi, H., \& Woyciechowski, M. (2013). Cocoon orientation in the nests of red mason bees (Osmia bicornis) is affected by cocoon size and available space. Apidologie, 44(3), 334-341. D0l: 10.1007/ s13592-012-0185-2

Teper, D. (2007). Food Plants of the red mason bee (Osmia rufa L.) determined based on a palynological analysis of faeces. Journal of Apicultural Science, 57(2), 55-62.

Teper, D., \& Bilinski, M. (2009). Red mason bee (Osmia rufaL.) as a pollinator of rape plantations. Journal of Apicultural Science, 53, 115-120.

Wilkaniec, Z., \& Giejdasz, K. (2003). Suitability of nesting substrates for the cavity-nesting bee Osmia rufa, Journal of Apicultural Research, 42(3), 2931. DOl: 10.1080/00218839.2003.11101084

Wilkaniec, Z, Giejdasz, K., \& Prószyński, G. (2004). Effect of pollination of onion seeds under isolation by the red mason bee (Osmia rufaL.) (Apoidea, Megachilidae) on the setting and quality of obtained seeds. Journal of Apicultural Science, 48, 35-41.

Wilkaniec, Z., \& Radajewska, B. (1997). Solitary bee Osmia rufal (Apoidea, Megachilidae) as pollinator of strawberry cultivated in an unheated plastic tunnel. 


\section{_ MCHOHAP Et fll. __ Optimal reed stalk for red mason bee nesting}

Acta Horticulturae, 439, 489-493. D0l: 10.17660/ ActaHortic.1997.439.83.

Williams, l., Corbet, S., \& Osborne, J. (2015). Beekeeping, wild bees and pollination in the European community. Bee World, 72(4), 170-180. DOl: 10.1080/0005772X.1991.11099101

Winfree, R. (2010). The conservation and restoration of wild bees. Annals of the New York Academy of Sciences, 1195(1), 169-197. DOl: 10.1111/j.17496632.2010.05449.x 